\title{
Why Gender in Wildlife Conservation? Notes from the Peruvian Amazon
}

\author{
M. Cristina Espinosa*
}

\author{
Assistant Professor in Gender, Culture and Development, Associate Director for Academics, Masters in Sustainable \\ International Development at The Heller School for Social Policy, Brandeis University, USA
}

\begin{abstract}
The connections between gender and wildlife use are diverse and depend on particular economic, cultural and ethnic contexts. Challenging the common exclusion of women from wildlife conservation, this article shows the important role played by gender even in situations where women are not direct users of wildlife. Women productive and reproductive unpaid work and their participation in decision-making have a direct impact in wildlife use by: 1) making male labour available to hunt or fish at times when seasonal demand for labour in agriculture peaks and 2) reducing monetary cost of family reproduction and generating alternative sources of income and supporting food production, all which might reduce pressure on wildlife. Gender also shapes different perceptions and attitudes related to wildlife, and when embedded in particular ethnic views, gender also affect use of natural spaces and wildlife species. Using interdisciplinary and applied anthropology perspectives, findings from field research conducted in the North Eastern Peruvian Amazon are used to define the role of gender in wildlife use and derive some implications for conservation interventions in this region.
\end{abstract}

Keywords: Gender, livelihoods \& wildlife, Women and the Environment, Gender and resource use in the Amazon.

\section{INTRODUCTION}

The need to include local communities in the management of protected areas, watersheds and forests have been recognized by conservationists since the 1980 s, even though the understanding and execution of this inclusion has not been homogeneous. While some conservationists champion its results, others question its effectiveness. Most agree on the need to better address differences within communities and the external factors affecting local sustainability [1-5]. Greater concern for including local people in conservation coincided with a mandate adopted by major conservation organizations like IUCN [6] to mainstream gender within conservation and natural resources management.

Extensive research on gender, development and natural resources management has supported the development of conceptual frameworks connecting gender with the political ecology of conservation and development. Gender has shown to play a key role in local livelihoods and shaping perceptions related to nature and conservation $[7,8]$. The connections between gender, wildlife use and livelihoods have remained less explored as compared to the role of gender in agroforestry or water management [8-12], which has contributed to maintain the perception that wildlife conservation is a male domain where gender plays no role.

Conservation programs in the Amazon struggle to integrate gender within their interventions since the connections between gender and wildlife use and conservation have not been clearly conceptualized and operationalized. This gap is further complicated by the fact that women do not have the same type of interactions with the environment in this

*Address correspondence to this author at the MA Program in SID - The Heller School at Brandeis University. Mail stop 035. Waltham, MA 02451 USA; Tel: +1 (347) 596 9312; +1 (781) 736 7660; Fax: +1 (736) 8366;

E-mail: espinosa@brandeis.edu region. While certain social groups seclude women from the forests [13], in other cases like the Matses of the PeruBrazilian border [14], the Ayore of Eastern Bolivia [15] or the Sirione of Bolivian lowlands [16], women are part of hunting expeditions or go alone to the forests for tapping trees as shown by Kainer and Duryea [17], Campbell [18] and Hecht [19] for the rubber tapers of the Brazilian Amazon.

The question remains: what is the role of gender in regard to wildlife use and conservation? The connections between gender and wildlife use are diverse as they depend on particular economic, cultural and ethnic contexts. Since in most situations women are not direct users of wildlife, there is a need for better understand the role of gender in situations where women are not direct users of wildlife. This is precisely the aim of this article. Women in the communities under study do not hunt or do commercial fishing, because ethnic views prevent women to access forests or rivers. Nevertheless, gender plays a very important role shaping livelihoods and interactions with nature, as will be presented in this article. Due to limitation of space, this article will focus on unveiling the invisibility of women in regard to wildlife use by connecting productive and reproductive spheres. A comprehensive gender analysis requires an exploration of masculinities as well as femininities in regard to wildlife, nature and livelihoods; however, this is beyond the scope of this paper.

Let's briefly define the way I am using terms like gender, livelihoods and wildlife use. Gender refers to the fact that the interactions between men and women are not naturally ascribed but socially constructed within specific social groups. Gender constructions or ideologies define the roles, entitlements, identities and perceptions of men and women in ways that differentiate their interactions with the natural and social worlds. Gender ideologies transform biological sexual differences into hierarchies that subordinate one sex group to 


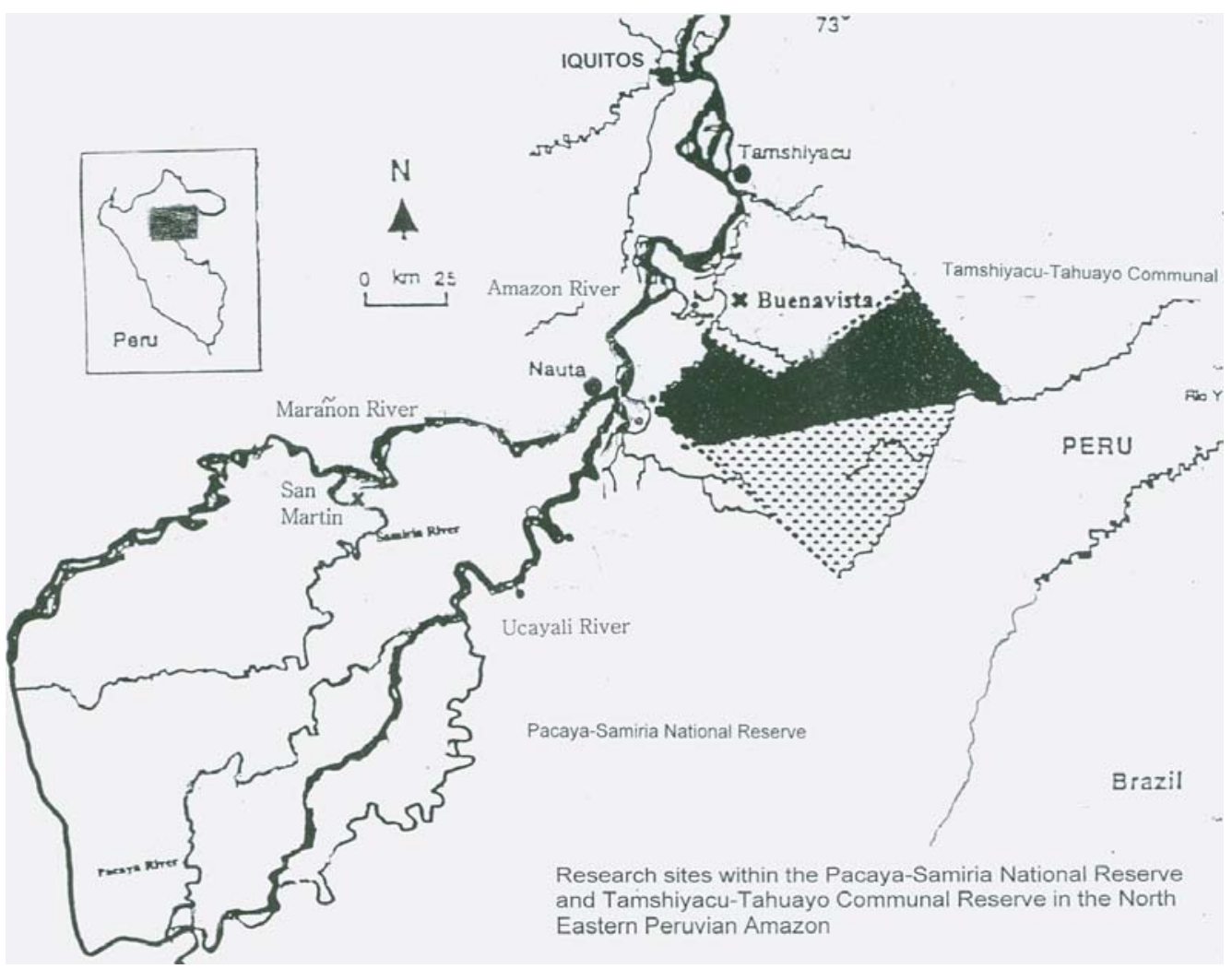

Fig. (1). Research sites within the Pacay-Samiria National Reserve and Tamshiyacu-Tahuayo Communal reserve in the North Eastern Peruvian Amazon.

the other. However, the fact that gender is highly contextual explains that men and women of different cultural, ethnic or class groups do not have homogenous gender systems; in addition, individuals negotiate gender according to their position in hierarchies like class, ethnicity, age or seniority and to their own life cycle and agency. Among people who struggle to make a living, like in the communities under study, gender might include not only subordination but complementarity and cooperation since men and women have to collaborate to make their livelihoods more resilient in highly uncertain and hostile environments.

The notion of livelihoods refers to the set of strategies, arrangements, activities and assets that households deploy to make a living in situations where their survival and wellbeing are threatened by natural and economic risks, disadvantaged access to resources and broader social exclusion. The connections between gender and wildlife has to be always established in the context of particular livelihoods, where men and women of different households have different roles, entitlements and behaviour, which have direct and indirect impacts on the pressure these families exert on wildlife. These livelihoods in turn reflect the political ecology of the region, which sets the limits faced by these households to make a living. For instance, what are the entitlements these families have in regard to forests and wildlife resources? What are the prices for agricultural products and the transactions costs? What alternative opportunities to make some cash have these families other than wildlife resources? It is within particular livelihoods that the roles and entitlements of men and women can be better visualized in connection to wildlife use. The notion of livelihoods connects the micro level (households and the community) where gender is more visible with the macro level (markets, prices, employment, agricultural policies, conservation policies etc.) where gender is less visible but not less important. Livelihoods also are important to understand the links between the material and the symbolic and the cumulative levels of subordination defined by gender, ethnic and class hierarchies, reinforced at the micro and macro levels.

Wildlife use refers to the broad spectrum of nondomesticated species used by local people to make a living. For this article, the notion of wildlife was reduced to hunting and fishing after the surveys revealed the lesser role of activities like collecting turtle eggs, harvesting palm fruits or, exotic plants and animals.

The main thrust of this article is that gender matters for wildlife use even in situations where women are not direct users of wildlife ${ }^{i}$. The key argument I make is that: a) women productive work in agriculture releases men to fish and hunt at times of the year when all these activities compete for male labour; b) women unpaid productive and reproductive work reduces the cost of family reproduction and therefore the pressure on wildlife, in situations where wildlife is mainly used for cash and less for consumption; and c) women's participation in key decisions related to wildlife (for instance, how much of the catch goes for sell or for consumption and sharing) and to livelihoods also affect the amount of wildlife used; d) gender also shape different experiences, perceptions and attitudes toward natural resources and their conservation. The article connects gender, livelihoods and wildlife use in the context of the political ecology of Loreto that sets the limits for what choices ribereño men 
and women can make in regard to their use of natural resources.

\section{METHODOLOGY}

This article looks at findings from field research conducted in the Loreto region of the Northeastern Peruvian Amazon Espinosa [13, 20], which focused on the political ecology of gender and wildlife use among Riparian villages of San Martín del Tipishca on the border of the PacayaSamiria National Reserve, and Buenavista, on the border of the Communal Reserve Tamshiyacu-Tahuayo (Fig. 1).

The study combined surveys with ethnographic methods and qualitative with quantitative analysis. 74 surveys were separately applied to husbands and wives of a randomly selected sample of 37 households (50 percent of the universe of study) ${ }^{\mathrm{ii}}$. Access to the Community Census of San Martin and Buenavista allowed the selection of a random sample and complemented the information from the surveys. Previous research and training in the region [21-25] expedited the survey design and test $\mathrm{t}^{\mathrm{ii}}$. The questionnaire included a demographic section about the household, detailed information about livelihoods and gender/age division of labour throughout the year, decision making, use of wildlife (location, catch, species, amount, destination, etc), perceptions about the status of natural resources, causes of resource degradation and attitudes towards conservation projects. Due to its length, the questionnaire was "applied" while participating in agricultural work or visiting with the family, usually taking a total of three working days to complete each survey. I interviewed spouses separately to capture the gendered different perceptions, views and knowledge within households. Even though focused on the surveys, informal interviews provided rich information on culture and ethnicity as well as on livelihoods, gender and wildlife use.

A second fieldwork was conducted in 1997 after the surveys were analyzed. Each of the initial survey participants was given a more in-depth interview, to better understand the patterns identified in terms of wildlife use and to have a better grasp of inter and intra-gender differences identified in the surveys. During this time I tried to integrate information gathered previously about spirituality, taboos and "traditional" views on nature into the analysis of patterns of wildlife use, gender and livelihoods [26, 27]. This phase also relied on ethnographic methods like mapping (women were asked to map and name the locations where their spouses hunted or fished in order to sell, as opposed to the subsistence fishing done everyday nearby), focus groups (one was conducted with the women organized in the Club de Madres, other with the community leaders and yet even other with hunters), structured interviews (10 in each village with men and women who were not in the survey sample) and unstructured interviews combined with participant observation to further explore trends obtained from the surveys.

Since the research aimed at identifying patterns of wildlife use and to understand the role of gender within particular livelihoods, the sample targeted women and men that were parents and heads of the household; it did not include single mothers, elders or single young men and women living in the same household. What I present here are views from the majority of adult men and women interviewed who were heads of household. Prevalence of ethnic cultural frameworks was slightly higher among those interviewed in San Martín than in Buenavista, bringing awareness to their different ethnic origins and composition of these communities, the different incidence of kinship structures, and the degree of integration to regional markets and urban culture. Buenavista is closer to and has better access to regional markets than San Martín. Buenavista evolved from a small estate settlement, while San Martín started as an independent village found by a Cocama family group. In addition, San Martín is more distant and isolated than Buenavista, which is closer to the regional market of Iquitos and the district head town of Tamshiyacu, with daily access to public transportation ${ }^{\text {iv }}$.

\section{Political Ecology of Loreto}

The regional economy of Loreto relies on natural resources like oil, wildlife, timber and non-timber products that are exported to Lima and abroad. Game meat, fish, cassava, plantain, seasonal fruits, and small livestock are produced in the region, but the rest of the food supplies are transported by air from Lima, which increases their prices. Lack of policies fostering economic diversification and agricultural development maintain economic stagnation and poverty.

Loreto's rural regional population is largely settled in small villages dispersed along Amazonian rivers. Riparian people (ribereňos) combine extractive and productive activities depending on their access to specific landforms and resources and to local and regional markets [28-31]. Smallscale extraction of wildlife and natural resources are both for sale and consumption, while large-scale timber and fishing concessions are operated by outsiders. Riparian livelihoods are limited by geography (floods and isolation) and by the regional political ecology that excludes them. While Loreto has historically provided a richness of natural resources (e.g, rubber, oil, precious timbers, wildlife), its population has remained extremely poor (Barham et al., [32]; Coomes, [33]; San Roman, [34]; Valcarcel, [35]; and Villarejo, [36]) $)^{\mathrm{v}}$. There is however the need to consider the process of economic differentiation within Riparian people, where those who have better access to natural and economic resources can experience a process of capitalization, as shown by Barham, Coomes, Craig and Tarasoff [32]. By contrast, my study focuses on more prevalent conditions where communities have limited access to resources, minimal internal economic differentiation and where families struggle to make a living.

Post-colonial ethnic politics in Peru strongly promoted mestizaje and assimilation (instead of integration) to incorporate native populations in the construction of a unitary and homogenous state, preventing them from claiming citizenship and thus retaining their ethnic identity. With expansion of markets, urbanization and migration, assimilation and mestizaje became socioeconomic and cultural phenomenon. In this context, native views and forms of organization could only exist in a relationship of subordination to hegemonic modernist views, discourses and structures. The only 'choice' for natives to avoid or reduce discrimination and poverty has been to assimilate, like the Cocamas in the area of study who erased external ethnic markers like language and dressing since the 1940s [37]. 
However, this process of assimilation faces structural limits since the market economy cannot absorb labour and goods produced by Riparian communities. In a situation of monopsodic markets ${ }^{\mathrm{vi}}$, low and unstable prices keep small scale agriculture unprofitable. Lack of industrialization and economic diversification explain high unemployment and the stagnation of Loreto's economy, which is heavily dependent upon extractive activities. The failure of markets to absorb rural production and labour is reflected in the structure of relative prices, the structure of supply and demand, and the lack of development of secondary markets. Prices for most rural products are highly volatile and sometimes too low to even cover the cost of transporting products to the market place, not to mention the cost of labour and other inputs. Families are desperately in need of cash and turn to wildlife extraction; its shorter cycle and lesser investment as compared to agriculture make it appealing despite low and volatile prices.

Wildlife prices paid by intermediaries are much lower than the prices of fish or game meat in regional markets. Enforcement of regulations protecting endangered species focuses on controlling the supply not the demand. While park guards can seize catches before they reach intermediaries, game meat is openly sold in regional markets, without any control. Low prices combined with the risk of confiscation and high transportation costs -especially for communities like San Martín, reduce the income families can derive from wildlife. Furthermore, since hunters cannot always afford the cost of hunting expeditions, sometimes they must depend on 'habilitadores' -some of whom are women, to finance expeditions paying interest and fees, which further reduces hunters' income [13, 38].

Emigration to Iquitos, Nauta or Tamshiyacu is high, explaining the rapid urbanization of Loreto. Since low-paid informal jobs keep migrants in poverty, many migrants return to their villages to raise a family, hoping their children would break the cycle of poverty through a better education [13]. Back in their village, families resort to "traditional" ways of building houses, preparing food, fishing, cropping and hunting to make a living without much income. This is not because they don't know other ways but because they cannot afford them. In turns, these conditions of poverty, vulnerability and marginality are also favourable for a process of cultural resistance, adaptation and recreation. The fact that natives and 'mestizos' remain at the margins of modernity, subordinated as producers, workers and citizens give them spaces of autonomy that are important for cultural resistance and recreation [33].

\section{Gender, Livelihoods and Wildlife Use: Framework}

We cannot begin to explore the connections between gender and wildlife use without recognizing the multiple roles and modalities of wildlife use associated with different livelihoods within the Amazon region. In some cases, hunting is done by almost every male head of household as a daily activity that does not take much time while provides meat for daily consumption (Minzenberg, [39] reporting for the caboclos of Acre, Brazil). In other cases, hunting is a very specialized activity restricted to few male heads of households, requires long expeditions to the deep forests and is mainly oriented to sale instead of family consumption
(Espinosa [13] reporting for the Riparian people of the Northeastern Peruvian Amazon). Sometimes women are hunters, as presented by Suaznábar [15] reporting for the Ayoré near Santa Cruz, Bolivia, Townsend [16] for the Sirione of Bolivia and Romanoff [14] for the Matses in the Peru-Brazilian border. Access to and control of wildlife resources, access to markets, transaction costs, alternative sources of income or food, cultural preferences, skills and affordability of means of extraction (type of nets to fish, ammunition, fire guns, traps) are factors explaining the different use of wildlife in situations where use of wildlife is more differentiated across households [13].

The diverse roles and modalities of hunting within the Amazon basin require researchers to frame the connections between gender and wildlife use in the context of specific livelihoods. Livelihoods can be defined as a set of arrangements and strategies within households that respond to their specific entitlements, access to markets, resources, information and networking and that allow households to maximize their resources and enhance their survival or well-being [40]. Livelihoods connect the individual men and women with the broader political ecology of resource use that shapes the choices they have and the pay-off of different activities. Lack of alternative sources of income or low returns for agriculture for instance after the structural adjustment program implemented in 1990 that eliminated subsidies and preferential credit and commercialization support for small farmers in Loreto, is associated with more intensive use of wildlife, as shown by Agreda [41] for the Riparian people of Loreto and by Escobal [42] and González de Olarte [43] at the national level. Better access to markets and lower transaction costs might act as incentives for more intensive use of wildlife, while there might be situations in which lack of alternatives force local people to extract wildlife for sale despite high transaction costs and limited access to markets [13, 44]. It is important to recognize that the role of fishing and hunting to provide food and cash is not the same everywhere. Unlike other areas of the Amazon [39], in the area of study poor families rely on subsistence fishing for food and use hunting or commercial fishing to obtain cash ${ }^{\text {vii }}$. For that reason, the monetary cost of family reproduction is an important element associated with the pressure local people exert on wildlife resources, especially when it becomes the ultimate source of cash. It is in this context that the role of gender becomes important as it affects the monetary cost of family reproduction and the social cost of reducing that monetary cost.

The role of gender in wildlife use will depend on the importance of wildlife for family consumption and income as compared to agriculture and off-farm activities, access and control to natural resources, and on the whole set of strategies deployed by households to survive and/or improve their livelihoods. The more diversified livelihoods are more resilient in the face of environmental and economic shocks; they usually involved complex arrangements and heavy work loads for women and men, where gender plays an important role in negotiating decisions and resources.

The specific role of gender in regard to wildlife use in different contexts is associated with issues such as: Is hunting and/or fishing restricted to men? What is the seasonality of fishing, hunting and agriculture? Do men have the time 
available to hunt or fish? How long it takes for men to hunt or fish? What alternative sources of income and food are available and what constraints do men face to hunt and fish? What economic incentives exist in terms of prices, access to markets, and lack of alternative sources of income? What constraints act as deterrents for men to hunt and/or fish? What cultural preferences influence men's decision to hunt and/or fish more or less and with more or less regularity? How much do they need to hunt or fish to satisfy cash or food family needs? How is the family size and age composition affecting the demand for hunting and/or fishing?

Gender has been defined as a social construction that within specific cultures and societies shapes the interactions between men and women, converting biological differences into social hierarchies that define differential entitlements, roles, identities and power for men and women. Gender interfaces with class, age, and ethnicity to influence the relationships people establish with nature and the way they use natural resources [7, 45-47]. Gender should not be reduced to women subordination, since in contexts where family survival is at risk, gender relations at the material and symbolic levels might combine subordination of women with economic inter-dependence and complementarity between men and women. Gender inter-dependence, complementarity and collaboration are rooted in the shared subordination of men and women - in terms of class and ethnicity - and in specific cultural frameworks that accommodate conflict and cooperation. All these dimensions of gender make livelihoods viable under extremely adverse circumstances. Gender as a social construct -defining roles and identities for men and women, is part of broader cultural systems of meanings that shape perceptions on nature, organize daily life and legitimize differences in social interactions, which are also the product of individuals negotiating meanings and views.

Families adapt to the conditions established by the regional political ecology that defines access to resources, roles, entitlements, opportunities and constraints. Livelihoods, therefore, express the articulation of gender, class and ethnic hierarchies at the local level and a process of adaptation and negotiation within households. In this article I focus on the role of gender, livelihoods in wildlife use and conservation (For an analysis on the role of macroeconomic policies, entitlements and market dynamics see Espinosa [26] and for the links between gender, ethnicity and health, Espinosa [44]).
Due to the invisibility of women, this exploration of the role of gender in wildlife use is focused on the roles played by women with respect to seasonal allocation of family labour, participation in decision-making, reduction of family reproduction cost, provision of food and/or income that contributes to the family survival and well-being, shared knowledge on wildlife use and environmental degradation and differential perceptions on wildlife use and attitudes towards conservation.

\section{Livelihoods, Gender and Wildlife Use: Finding}

1. Women productive work in agriculture releases male labour to hunt or fish at times when seasonal demand for labour in agriculture also peaks and competes.

As presented in Table 1 Seasonal Peak of Wildlife Use and Agriculture floods in the Amazon flood plains make wildlife extraction and agriculture highly seasonal: during the ebb, fish populations are small and concentrated; when the rivers rise, fish migrate into permanent lakes (cochas) or flooded forest (tahuampas) and reproduce (fish migration upriver is called mijanos and occurs two or three times per year). Game meat is easy to hunt during floods when the river is high and mammals concentrate on the diminishing dry terrain. Hunting is therefore more intense during floods and when floods recede fishing becomes more intensive since fish trapped in the cochas or tahuampas are easier to catch.

Agriculture is also highly seasonal in villages like San Martín, where lack of high levees [restingas] restricts agriculture to the months when floods recede. In these cases, agriculture and fishing peak during the ebb months, placing competing demands for male labour.

Villages with access to high levees can maintain agriculture during floods. In cases like this, in Buenavista for instance, peak demand for agricultural labour extends to the flood season when hunting season coincides with cropping in the high levees. It is during floods that harvest of non-timber forest products tend to intensify, fuelled by the economic needs of families that need to buy food and by the easier access by canoe to remote forest areas where these products are more abundant.

Therefore, an important constraint faced by families is the seasonal multiple demands for male labour. Male availability for hunting and fishing during certain times of the year is enhanced by strong female involvement in agricul-

Table 1. Seasonal Peak of Wildlife Use and Agriculture in the Area of Study

\begin{tabular}{|l|l|}
\hline Ebb - July-September & Floods -March -May \\
\hline \hline Fishing: more intensive since fish are trapped in tahuampas & $\begin{array}{l}\text { Fishing: Less intensive since fish are more dispersed in rivers, cochas \& ta- } \\
\text { huampas }\end{array}$ \\
\hline Hunting: Less intensive since mammals are dispersed in forests & Hunting: more intense since mammals are trapped in high levees \\
\hline $\begin{array}{l}\text { Agriculture: more intense for communities that only have access to } \\
\text { lowlands }\end{array}$ & $\begin{array}{l}\text { Agriculture: continues for communities that have access to high levees and } \\
\text { uplands }\end{array}$ \\
\hline Other extractive activities in far locations: less intensive & $\begin{array}{l}\text { Other extractive activities: more intense since flooded forests allow canoes to } \\
\text { reach catch areas for easier transport }\end{array}$ \\
\hline
\end{tabular}


ture. As multiple demands for male labour increase, women play a more active role in agriculture during the clearing, planting, weeding, and harvesting. While men are busy hunting, fishing, or collecting, women tend crops so crucial for food and income.

Information from the surveys show women labour in agriculture representing $20 \%$ of total labour (according to male informants) and $27.4 \%$ of total labour (according to female informants), as compared to male labour representing $41 \%$ and $45.3 \%$ of total labour (according to male and female informants) and shared labour representing $28.7 \%$ and $25.3 \%$ (according to male and female informants).

Men handle the heavy tasks of clearing plots, which require reciprocal exchanges of labour (minga); women invite relatives and neighbours for the minga, and prepare a native brew called masato and food for the participants. During the clearing, women cut small trees and weeds with the machete, move them, and prepare them for burning. Women perform the planting and the weeding themselves, while the harvest involves the entire family, especially when the fields are threatened by floods. Women play an additional important role in agriculture: they are in charge of seed processing, selection, preservation and exchange. Since families cannot afford to buy seeds, this role is particularly important to ensure cropping year after year.

Despite its importance, the productive role of women is usually not recognized, since perceptions on gender roles do not always coincide with labour allocation by gender ${ }^{\text {viii }}$. For instance, agriculture is perceived by men and women as mainly a male activity, even though, male labour contributes only for 41 to 45 percent of total labour as compared to women labour that accounts for 20 to 27 percent of total labour. Why then, is agriculture considered a male activity despite the important role performed by women? Some researchers express caution when interpreting gender differences in time allocation without considering both the type of energy spent during these hours [49] and the fact that men and women roles in "traditional" livelihoods demand different displays of energy. For instance, men conduct less continuous activities that demand intense energy while women perform continuous activities that demand less energy [50, 51]. This might explain the fact that men performing the heavy tasks get more recognition even though women make a more sustained contribution to agriculture in terms of labour. There are other elements explaining this gap between gender real and perceived roles, as presented in section 4.

\section{Women reproductive unpaid work reduces the monetary cost of family reproduction and therefore the family de- mand on wildlife for cash, in situations where wildlife ex- traction is mainly for sale and less for family consumption;}

In San Martín and Buenavista, hunting is done mainly for sale and it requires 10 day expeditions into the deep forests. There is a difference between daily small scale fishing (done with hooks and nets) and for-sale fishing done in two to four day expeditions to cochas or tahuampas nearby the community (done with special nets and traps). Families desperately need income to buy food and basic goods they cannot produce $^{\text {ix }}$ because of flood cycles, low yields, and small size of plots-limited by their family labour. Local diet relies on small fish, cassava and fariňa with occasional consumption of eggs, chicken or game meat shared by hunters. Even though families in these communities severely comprise their food consumption, they still have to purchase some food and basic goods. Due to limited food and poverty, families only eat two meals per day: around 10 a.m. and 5 p.m. Female subordination within households is revealed in food distribution: men are served the best portions first, followed by the children, only then the mothers, and finally the elders.

Reproductive unpaid labour of women has been identified as an important factor reducing the cost of labour reproduction, connecting gender with macroeconomics and the process of capital accumulation [52, 53]. In the context of livelihoods that rely more on natural resources and less on the production of tradable goods, the role of women unpaid domestic work reducing the cost of family reproduction is important not only to keep low salaries but to lower the pressure on natural resources for cash.

Women reproductive unpaid labour include tasks done within the household as well as tasks performed outside the household that reinforce reciprocal and kinship networks. Cooking, washing clothes, doing dishes and pots, cleaning the house and fetching water are daily chores performed by adult women with some support of girls, and in the case of fetching water, from boys as well. It is important to address the rustic living conditions that make domestic tasks more demanding. For instance dishes and pots are cleaned on the river shore using ashes and water, no detergent. Preparing food is usually done over the floor using very rustic materials and cooking is done in open wood fire that takes longer and produces constant smoke. Adult women surveyed in San Martín and Buenavista report spending an average of four hours per day cooking, two hours washing cloths in the river, one hour per day taking care of domestic animals and cleaning the house and variable time on errands. There are also periodic activities like the monthly school meeting (four hours approximately) or sewing or repairing clothes that are variable among households. Taking care of sick children or relatives is an important and demanding role for women. The contribution of men to domestic work is their weekly provision of fuel wood since women are not allowed to go to the forests or the occasional purchase of food and basic supplies when men go outside the community to sell some harvest or catch. The fact that men sometimes spend the little cash obtained in items that are not basic goods for the family generates conflicts within the household ${ }^{\mathrm{x}}$.

Livelihoods are made more resilient by strong reciprocal links based on kinship and/or affinity. For instance, game meat is always shared by hunters within their kin groups. Since available cash is limited, families borrow anything they need from each other, from a cup of sugar to agricultural tools. They also share information and knowledge and gossip about each one's every day business, thereby exerting strong social control on individual behaviour. Reciprocal labour called minga allows the timely completion of certain agricultural tasks like clearing a plot. Women play an important role in maintaining these reciprocal informal networks. For instance, women are the ones who invite participants for a minga, and they prepare a native brew call masato and food for the participants in the working party. Women also take care of relatives and neighbours when they are sick or delivering a baby. These reciprocal networks are part of local 
culture and support economic strategies that avoid spending cash and rely on social capital. Women's reproductive role therefore expands beyond the household to reduce the cost of family reproduction and enhance livelihoods' resilience. This, in turn, helps to reduce the pressure on wildlife to obtain cash.

3. Women participate in decisions related to wildlife, for instance, defining how much of the catch remains for family and kin consumption and how much goes for sale, or how to use the cash generated, all which affect the pressure for harvesting wildlife.

The majority of women surveyed participate in most decisions affecting the use of wildlife. Most men and women in San Martin and Buenavista share important decisions such as how much to keep for consumption and how much to sell (in $93 \%$ of cases as reported by men and $97 \%$ of cases as reported by women). Control of the money earned by selling fish and game meat is variable in both communities: in $60 \%$ of households in San Martín and $45 \%$ in Buenavista husbands make final decisions on the use of this money. Husbands and wives share decisions about money obtained from wildlife in $40 \%$ of cases for San Martín and 55\% of cases in Buenavista. These findings show that even in situations where women are not direct users of wildlife, they still have a role in decisions related to wildlife, including how to spend the cash it generates. Women interviewed also share decisions with husbands about agriculture, children education and emigration.

Interdependence and collaboration between men and women gives women bargaining power in decision-making; however, female subordination makes bargaining power contingent to gender asymmetries, for instance when husbands waste money or abuse wives. Female subordination is expressed at several levels, for instance in lack of autonomy for women to decide on their reproductive health and sexuality, which is aggravated by their poverty and lack of access to public health services. Lack of female control of their fertility underlies the high demographic growth experienced in Loreto (the highest for the country), which increases human pressure on the fragile ecosystems and on wildlife.

4. The subordinated and submissive behaviour of women at the public level might hide women's active participation at the household level in decision-making related to wildlife use, and women's access to knowledge shared by husbands about their extractive activities, in terms of specific locations, amounts and species caught. It is important to understand that gender relations can include cooperation and inter-dependence as well as subordination and that these elements are more or less prevalent in the public and private spheres.

The difference between real and perceived gender roles in regard to agriculture (presented in section 2) is related to the ways local men and women relate and understand gender differences. Since gender relations in private and public spaces differ, men and women behave differently within the household and at the public level in the village. Subordination, complementarity, and cooperation are more and less predominant or visible depending on whether gender roles are performed in public or in private. Assigning men certain leading roles in public while sharing some decisions in pri- vate is part of the multiple dimensions of gender in this area. One woman explains:

"The man is like the speaker of the house. We don't want to ruin his performance, which is why we don't speak when he is present. However, when we are alone at home, in our bedroom, then we discuss and review the different choices, and together we reach an agreement. That's the way most families make decisions here. Of course, there are some men who are arrogant and foolish and don't listen to their wives. But sooner or later they learn to do so, since they fail many times when making decisions alone. Two heads think better than one, and women always have a better sense of reality than men do. Men have the physical strength and stamina, sure, but they don't get the whole picture as easily as women do, you know, to be able to see not only the present moment, but beyond."

\section{(S.Y., 42, Fieldwork 1997)}

This testimony reveals the complexity of gender relations and the need to contextualize gender within local views and perceptions, thus avoiding or reducing our own cultural biases. Gender is a multidimensional phenomenon where differences and conflicts coexist with complementarity and mutual dependence, which are framed within particular ethnic views where differences might not always mean subordination.

Gender economic interdependence is acknowledged by men and women interviewed as necessary in the context of their vulnerable livelihoods that requires the strong cooperation of both men and women. Economic interdependence and the importance of women's labour provide a basis for collaboration and negotiation between men and women, manifested in the sharing of knowledge and decisions. However, this interdependence coexists with female subordination, which seem to be reinforced by ethnic views, discourses of modernity, markets and the conditions of poverty.

Male supremacy is reinforced when the market economy assigns more value to money-generating activities over activities for subsistence, which in the area of study tend to be performed mostly by women. Additionally, ethnic views consider women weaker than men and dependent upon them, thereby reinforcing female subordination. Female subordination in public spaces is reinforced by the communal organization that only recognizes men as household heads, with the only exception being widows. Women attend community meetings or work only in place of their husbands ${ }^{\mathrm{xi}}$. Women sit together, apart from men and do not participate when attending community meetings. Female subordination is further reinforced in the public sphere by the lower access women over forty have to formal education. This subordination extends beyond husbands to other male figures such as fathers and brothers, community leaders, priests, school teachers and project staff ${ }^{x i i}$.

Despite the segregation of natural spaces by gender, the majority of women surveyed show quite accurate knowledge about the extractive activities carried out by their husbands, in terms of location and the quantities and species of wildlife captured: 97 percent of women were able to identify and map at least two of the four locations used by their husbands to fish or hunt, and to list most frequently-fished and hunted 
species of animals. Information provided by women was consistent with that provided by their husbands, evidence that men and women share information about activities that are done separately.

Even though natural spaces are segregated by gender, not all men or all women relate to these spaces in the same way. For instance, medicine women go deep into the forests to collect medicinal plants. They have the spiritual knowledge and power to negotiate nature and its spirits in ways others cannot, thanks to their knowledge of rituals. Not all men hunt: some do it occasionally and others avoid it completely and focus on fishing and cropping. Only few families (10\% of all families in San Martín and Buenavista) had a dedicated hunter engaged once or twice a month in hunting expeditions that last between 10 and 15 days.

It is interesting to note the prevalence of spiritual rituals for protection performed by hunters before and at the beginning of the hunting expedition ${ }^{\text {xiii }}$. All hunters interviewed highlighted their preference for being in the open forest as the main reason to engage in hunting expeditions that last up to 15 days. While they mentioned the high economic return obtained from these expeditions, they were also aware that the money made was quickly spent buying food they could not produce and paying back habilitadores. Unlike hunters, local healers are among the better-off, perhaps because there are few healers in the area, which keeps them busy. While there is no gender restriction in this area for becoming a healer, it is taboo for any woman to hunt.

Intra-gender differentiation is also reflected in the economic status of women: few have better access to income than other women or men. Some women even finance hunters who cannot afford the rising cost of hunting expeditions. Women who are better-off had a steady source of income such as a widow pension from a policeman or from providing room and board to local school teachers, income which had enable them to invest in a small shop and/or financing hunting expeditions as "habilitadoras".

\section{Gender intersects with ethnicity to shape the interaction men and women have with nature, since ethnic views pre- vent women to access forests and rivers and influence the harvesting of certain wildlife species.}

Men and women have different relations with nature since natural spaces in San Martín and Buenavista are socially segregated by gender: forests and rivers are places where women are not allowed to go. This segregation of spaces is based on ethnic views that persist despite ribereños' access to markets and schools and their assumed assimilated mestizo identity. Similar gendered segregation of spaces has been reported by Minzenberg [39] for the caboclos of Brazilian Amazon.

According to local animist views, every person, plant, object and animal has a spirit and these spirits interact with each other. In these interactions, powerful objects, animals and plants have the ability to "cutipar", that is, to affect someone's field of energy causing disease and even death to individuals who are weak or vulnerable. Women and children are considered to be in this category, and for that reason, there are regulations, taboos and restrictions to "protect" them. These restrictions refer to places where women cannot go, food they cannot eat -especially during their pregnancy or menstrual period, and special care for infants ${ }^{\mathrm{xiv}}$.

Forests and rivers are considered dangerous for there are places where many spiritual entities live, such as evil forces of the underground world and the souls of the dead unable to go to the upper world (tunchis) can bring illness or even kill those who are weak. It is in the forests where the Mother (madre) of the plants, animals and the river also dwells. Most hunters perform rituals before starting their expedition, aimed at cleansing, obtaining protection from evil spirits and attracting good hunt. Once in the forest hunters ask permission from the mother spirit of the animals they want to hunt, and during the nights they smoke a special tobacco called mapacho, to keep away tunchis and other evil spirits. Women should stay away from forests and rivers to avoid dangerous spiritual entities inhabiting these places.

Restrictions extend to what pregnant woman can and cannot eat in order to prevent sickness or abnormalities in their babies; for instance, eating turtle or armadillo-animals living in holes, could cutipar the fetus, preventing the baby to come out at the moment of delivery; eating fruit which texture is too liquid could cause the baby to be born with endless diarrhea. Prohibitions known as covada or cuvada ${ }^{x v}$ extend to the activities the father can perform before and after his child's birth: the husbands of pregnant women should not be killing snakes or eels or even driving a motor boat. These beliefs restrict access of women to forests and rivers and also influence what species are appropriate for men to hunt and fish during their wives pregnancy.

The importance of culture in shaping gender division of labour might explain why similar activities related to processing cassava have different gender roles in these communities. Cassava is processed into a native brew called masato, as well as into dry granulates called fariña, to be eaten with fish or alone as a snack. While either men or women can prepare fariña, it is taboo for men to prepare masato, which is always a female activity. Ethnic narratives always mention a basic gender division of roles where men go hunting and women prepare masato at home, while there is no reference to preparing fariña. The fact that masato is always mentioned in native myths of origin ${ }^{\mathrm{xvi}}$ while fariña is not might explain that either men or women can prepare fariña while only women can prepare masato.

This evidence calls attention to the different meanings associated with wildlife use, where ethnic and gender views intersect to define what is or not appropriate to hunt, to fish, to do, or where to go. These meanings are important to consider in addition to the economic needs that drive local people to extract wildlife.

6. Men and women work to generate food and cash, however each assign different weight to activities like hunting, fishing, cropping or raising small livestock for food or cash; this different assessment of particular activities for providing food or cash is based on the different productive roles of men and women.

Families obtain some cash by selling fish, game meat, forest products, crops, small animals and sometimes handicraft produced by women. Women cropping provides food for the family and some income from sales. In addition women keep some domestic animals that they sell once a 
month or in cases of need. Women alone or with men process farina from cassava for family consumption and for sale. Only women brew masato from cassava mainly for family consumption or for a minga.

Men and women identify fishing as the most important activity for income generation, followed by agriculture. Men rate hunting as higher for income than women do, most likely because they tend to have greater control over the income generated by this activity. Another mutually-agreed upon income-generating activity is raising domestic animals. Men, however, tend to understate this activity that is performed and controlled by women. Men and women seem to assign different weight to particular activities for generating income because control of this income is differentiated by gender. Therefore, women and men seem to underestimate activities on which they have less or no control. This is an important finding, as it highlights the gender bias of information provided by men and by women on activities they do not control. This is an important issue, considering that most if not all information collected on wildlife use and livelihoods relies on male informants.

7. Local perceptions on natural resources' depletion and attitudes towards conservation are different for men and women.

The surveys and interviews revealed different gendered perceptions on environmental degradation. Women are more concerned about next generations not having enough natural resources to make a living, while men are more focused on the challenges they face to make a living now. Women report more specific causes of resource depletion, such as using better fishing nets, human demographic growth in the area, and increasing market demand for wildlife and forest resources. Men are more reluctant to report specific causes of resource depletion and less ready to compromise their use of forests.

While ethnic spiritual views still permeates the daily life of families in San Martín and Buenavista, native knowledge on biodiversity is progressively being lost: $95 \%$ of women and men reported limited knowledge of forests, rivers, medicinal plants, agriculture, and social organization, as compared to what they perceived their parents and grandparents to have known. While some families knew how to treat headaches, diarrhoea, and colds using herbal and traditional methods, most families relied on modern medicine provided by projects operating in these communities. The surveys did not reveal significant difference associated with gender in terms of loss of traditional knowledge about forests and rivers, despite the use of these spaces is quite segregated by gender, as noted earlier. This confirms that men share with their wives knowledge about activities done in forests and rivers.

Most adult women interviewed seem afraid of forests and rivers, making constant references to abovementioned taboos. Differences across generations becomes an important element: youth tend to find closeness to nature and life in the village more oppressive and are looking for a way out while older people seem to conform more to life in the village and seem more tuned with nature. All men and women interviewed, however, had strong similar expectations for their children to leave the village and "become something", to have a different life from theirs, to avoid becoming like them; this overwhelming attitude clearly reflects the frustration felt by adult men and women, their awareness of the hopeless and futile efforts to overcome poverty and discrimination. They all hope their children will take advantage of better access to public education to escape their fate. There was no gender differentiation in terms of the expectations they had for their children and their future.

8. Gender has been linked to environmental degradation through demographic issues like demographic growth resulting from high fertility rates and early pregnancies, as is the case of Loreto, where demographic growth and urbanization has increased pressure on ecosystems and wildlife. However, when comparing use of wildlife across households at the local level, demographic characteristics of households seem to have no influence on different levels of wildlife harvest. Data from the surveys show no clear correlation between family size, age of the hunter or fisherman, stage of life and family cycle, and different levels of wildlife extraction. Information from interviews and focus groups identify access to means of extraction, skills, cultural preferences, entitlements to resources and access to markets as closely related to differential use of wildlife for sale, within families of the same community and across communities. These findings suggest the correlation between family size and wildlife extraction is not direct, but mediated by factors related to poverty, lack of access to means of extraction, cultural preferences, and access to natural resources and markets.

One of factors connecting gender with environmental conservation is demographic growth, which has targeted women in the Amazon for fertility control interventions. Higher fertility rates combined with early pregnancies in Loreto explain the steep demographic growth experienced since 1960, and the process of urbanization expressed in the creation of new Riparian communities, increased size of existing ones and unplanned growth of Iquitos and district head towns. Demographic growth and urbanization has increased pressure on Amazonian ecosystems in terms of resource depletion, habitat disturbance or destruction and urban waste and pollution.

However, we should be careful before assuming that larger or poorer families are necessarily making more intensive use of wildlife resources. The study tried to identify some factors associated with larger or more frequent catches for hunting and fishing. When compared in terms of age, the youngest head of households in Buenavista and San Martín, and when compared in terms of years living at the village, those living 40 years or more have a higher catch for commercial fishing. However, the P-value does not show statistical significance for the differences observed in the distribution presented for age and time of residence.

Family size is not directly correlated to the size of the catch for subsistence fishing or for hunting since there were cases of men with larger families catching less wildlife. Even though not enough data is available to explore statistical significance, information from interviews and surveys seem to indicate that access to certain means of extraction (5' $\mathrm{x} 4$ ' nets, and special threat and materials to prepare a commercial trap, fire guns, ammunition, etc.) cultural preferences and specialized skills to track, hunt and live in the forests for 
long periods, or to find fish species with better market value are more clearly associated with the size of the catch and the frequency of the expeditions.

For the case of fishing for sale, it seems that all men have similar skills but different access to special nets and traps. Only those who had better access to nets and traps for commercial fishing were reporting larger catches. Many men interviewed explicitly stated they were not able to catch more fish to sell because they could not afford commercial nets to catch those species that had a better price in regional markets. This might suggest that poverty can be a deterrent for more intensive use of certain resources, when it depends on certain means of extraction, like the case of commercial smaller scale fishing. For the case of hunting, the data show those men hunting more had not only the skills, but the cultural preference, even if they had to use habilitadores to finance their expeditions. In this case it was clearly an issue of preference and having the skills, as expressed by these testimonies:

I do not like to go, to be in the open forest for days and nights, sleeping badly, exposed to dangers. I like to work my plot and fish nearby. Because I see that, sure, the rebusqueadores ${ }^{\text {xvii }}$ they get money fast but they also spend money fast, either drinking heavily or paying the bills for food their family has bought when they were away. And they are always away from their families. What's the point of living like that?

(D.C., 65-San Martín, Fieldwork, 1996)

In the case of our neighbors, the wife is the one who habilita hunters. ${ }^{\text {xiii }}$ Her husband started going to hunt with her money. The first trip went well, he caught five pacas. ${ }^{x i x}$ The second trip the canoe overturned and everything was lost. He has not agreed to go back to hunt since then.

(A.F., 67-Buenavista, Fieldwork, 1996)

\section{DISCUSSION}

Despite gender ideologies hiding the relevance of women in 'male' domains like wildlife use, gender is important even when women are not the direct users of wildlife. The study shows that women's labour in agriculture, domestic livestock and reproductive tasks are crucial to secure livelihoods in a context of extreme poverty, high seasonality and vulnerability. Women labour in agriculture allows men to fish, hunt and extract natural resources in times when high seasonality of these activities competes for male labour. Women are important players in their households and villages, even though their voices are expressed through their spouses at the public formal level. Women and men have different perceptions about causes of resource depletion. They also weigh activities for cash and consumption differently. Women and men make joint decisions on several productive and economic issues: how much of the catch is kept for consumption and how much goes for sale. In $40 \%$ of cases in San Martín and in $55 \%$ of cases reported in Buenavista, men and women also share decisions about income generated from wildlife extraction.

Women play important roles in local livelihoods, have acquired knowledge on and are involved in decisions related to wildlife use. Communication among spouses gives women access to knowledge about wildlife use and confirms that gender relations in this area combine complementarity and inter-dependence with women subordination. $97 \%$ of women interviewed could list species and amount caught by their husbands, as well as map and name at least two of the four locations used by men to fish and/or hunt.

What implications do these findings have for conservation interventions? What provisions should be made for including gender into wildlife use and management?

While gender is very important to understand wildlife use, it does not exist in isolation as shown in this article. Therefore, integrating gender into conservation interventions requires framing gender within particular local livelihoods that respond to regional political ecologies. Bringing gender experts who lack familiarity with local livelihoods, wildlife use and local cultural/ethnic frameworks is not only unproductive, but counterproductive ${ }^{\mathrm{xx}}$. Doing so will only reinforce stereotypes and "prove" that addressing gender is a waste of time.

The high socio-economic, gender and ethnic diversity of the Amazon space require conservation and development interventions to invest in research and training programs that can prepare staff to understand the basic interactions between gender, livelihoods and wildlife use, in the different forms in which they might unfold particular contexts, and to identify what implications these particular interactions have for their interventions. Results from one area cannot be "applied" to another area that has different characteristics and dynamics. Training programs informed by updated research results on gender and wildlife use and by comparative analysis of how they interact for different areas and different socio-economic groups might produce guidelines and materials that can truly help projects to identify in their particular areas how these interactions occur and how they affect their interventions.

While research and training on gender, livelihoods and wildlife use might raise the cost of these interventions, they have much to offer. For instance, the inclusion of women as informants might provide more detailed information to complement and refine information provided by men on livelihoods, wildlife use and drivers of resource depletion. It is also important to consider that some women finance hunting expeditions and play a more direct role in regard to wildlife use. Including women as active and equal participants might help interventions to define targets that better link wildlife use with livelihoods and that might benefit a broader range of family and community members. It is also important to remember to speak with women separately to avoid men dominating the interview.

Considering the influence of women in decision making and including women as real participants, interventions might increase the chances of interventions to influence decisions made by men and women, in regard to wildlife use. However, their choices are limited by the options their livelihoods made, which are defined by the political ecology of the region. In this regard, findings presented in this article corroborate Mayoux [56] in that while gender equity is an important step towards social inclusion and sustainability, it is not sufficient. Conservation organizations might need to broaden their focus on local interventions focused on biodi- 
versity conservation to include policy work influencing macro economic and regional policies, especially those affecting prices for agricultural products, transaction costs and off-farm employment opportunities, as they define choices men and women have to secure food and income. As long as the regional political ecology in the Amazon accentuates poverty and social exclusion and does not provide alternative sources for income, local communities cannot be expected to regulate their use of wildlife use and forests when their own survival is at risk.

While findings presented here are limited by the size of the sample and cannot be generalized for the whole Amazon, they call attention to the need to better integrate gender, livelihoods and political ecology, which are usually isolated in specific fields. Findings show the relevance of gender for wildlife use and conservation even in situations where women are not direct users of wildlife and the need to frame gender dynamics within local livelihoods and the regional political ecology that define their limits.

\section{FOOTNOTES}

${ }^{\mathrm{i}}$ Direct users are those who extract wildlife resources and control income generated from these resources.

${ }^{\mathrm{ii}}$ The independent nature of the study -clearly separated from the projects working in the area and the request for voluntary participation of informants was clearly explained at public community meetings in San Martin and in Buenavista at the beginning of the field work and the anonymity of informants was carefully protected since I was the only in possession of the names of informants surveyed and interviewed (codes were used instead of names for each survey).

${ }^{i i i}$ For instance multivariate analysis allowed the identification of different productive strategies associated with different access to landforms and resources and with different household composition and gendered household headship [25].

${ }^{\text {iv }}$ A further exploration of the role of differential market access and entitlements to natural resources in regard to wildlife use for San Martín and Buenavista and the role of macroeconomic policies on wildlife use is presented in [26].

${ }^{\mathrm{v}}$ There is a rich body of literature on ribereño economy and society [30,36-39], on the political economy of natural resources [29,31,40-42], and on traditional knowledge, native peoples, and biodiversity [43-46]. Gender, livelihoods, and the use of wildlife in this region have remained less studied $[13,24,41]$.

${ }^{\mathrm{v}}$ This type of markets have large numbers of producers of similar products (plantain, cassava, pineapple, papaya) competing to sell their products to few buyers or intermediaries who control prices to their own benefit.

${ }^{\text {vii }}$ Subsistence and fishing for sale are done in different locations, using different means of extraction and imply different time demands

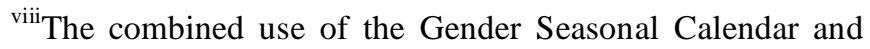
the Gender Activity Profile tools made visible the differences between real labor allocation by gender and gendered perceptions of this allocation [46, 48]. These tools facilitate the organization of data in ways that help to visualize gendered patterns. I used data from the surveys to fill these tools and contrasted them with information obtained from interviews and focus groups

${ }^{\text {ix }}$ Plot sizes are limited by the labor available to clear it. Clearings are labor-intensive and can be only done after the floods, when male labor has competing demands for fishing and trading. For this reason even though access to land is not limited within the communities under study, use of land is limited by family labor or cash to hire help. This explains food scarcity and famines brought by floods in a region so rich in biodiversity.

${ }^{\mathrm{x}}$ In one such occasion the wife threatened the husband to feed him "bicycle soup" for a month, after him spend money buying a bicycle instead of food and basic supplies.

${ }^{x i}$ Communities have an absentee fine for those members not attending meetings and/or communal work. For that reason, women will attend these events when their husbands cannot, to avoid the fine.

${ }^{x i i}$ Hunters ask permission to the mother spirit of the animals they want to hunt. They 'diet (They do not consume salty or spicy food or engage in sex for two days before they depart) before starting an expedition and smoke a special tobacco called mapacho' to keep evil spirits away at night.

xiii People living in Iquitos and in other parts of the Amazon basin share these beliefs [54].

${ }^{x i v}$ Not the same as couvade used within ethnography to refer a man experiencing the pain of delivery while his wife is giving birth to his child.

${ }^{\mathrm{xv}}$ Native myths of origin in the Amazon portrayed men hunting and women cropping, preparing masato, and doing domestic chores. (Programa Pacaya Samiria Report on Cocama Cosmo Vision Iquitos PPS 1996 and Cartinari 1997, interview [55]).

${ }^{x v i}$ Local term used for those relying mainly on hunting and commercial fishing for subsistence.

${ }^{\text {xvii }}$ Habilitar or to supply is to finance hunting or fishing expeditions in return for receiving the products of those trips; once the products are sold in Iquitos and the loan is discounted, the hunter or fisherman receives what is left.

xviii $\mathrm{Paca}=$ Majaz = agouti pac.

\section{REFERENCES}

[1] Chambers RE, McBeth MK. Community encouragement: returning to the basis for community development. J Commun Dev Soc 1992; 2(3): 20-38.

[2] Western D, Wright RM. Natural Connections. Perspectives in Community-based Conservation. D.C.-Covelo Washington, Ed. California: Island Press 1995.

[3] Bissonette BJ, Krausman PR. Eds. Integrating People and Wildlife for a Sustainable Future. Bethesda, Maryland: The Wildlife Society 1995.

[4] Brandon K, Redford KH, Sanderson SE. Parks in Peril: People, Politics and Protected Areas. Washington, D.C: Island Press 1998.

[5] Agarwal A, Gibson CC Eds. Communities and the Environment. Ethnicity, Gender, and the State in Community-Based Conservation. New Jersey and London: Routledge University Press 2001.

[6] IUCN, Union The World Conservation. Mainstreaming Gender in IUCN. A Policy Statement. Gland: IUCN 1998.

[7] Rocheleau D, Thomas-Slayter B, Wangari E. Eds. Feminist Political Ecology. Global Issues and Local Experiences. London and New York: Routledge 1996. 
[8] Leach M. Rainforest Relations. Gender and Resource Use among the Mende of Gola, Sierra Leone. Washington D.C.: Smithsonian Institution Press 1994.

[9] Roda A. Ed. Women and the Environment. London: Zed Books 1993.

[10] Braidotti R, Charkiewicz E, Hausler S, Wieringa S, Eds. Women, the Environment and Sustainable Development. Towards a Theoretical Synthesis. London: Zed Books 1994.

[11] Agarwal A, Bina. Conceptualizing environmental collective action: why gender matters. cambridge. J Econ 2000 24(3): 283-310.

[12] Harris L. Irrigation, gender, and social geographies of the changing waterscapes of southern anatolia. Environ Planning Soc Space 2006; 24: 187-213.

[13] Espinosa MC. Differentiated Use of Wildlife Resources by Ribereño Families of the Northeastern Peruvian Amazon. PhD [Dissertation] Gainesville (FL): University of Florida 1998.

[14] Romanoff S. Women as hunters among the matses of the peruvian amazon. Hum Ecol 1983; 11: 339-43.

[15] Suaznábar EB. Identidad Étnica y de Género. Posición de Género de la Mujer Ayoré en Cambios Culturales. Licenciatura [Thesis] Cochabamba, Bolivia: Universidad Mayor de Cochabamba 1995.

[16] Townsend W. R. Ed. Nyao Itô. Caza y Pesca de los Sirionó. La Paz: Instituto de Ecología 1996.

[17] Kainer K, Duryea M. Tapping women's knowledge: plant resource use in extractive reserves, acre, Brazil. Econ Bot 1992; 46(4): 40825.

[18] Campbell Connie with the women's Group of Xapuri. Out on the Front Lines but still Struggling for Voice. IN: Rocheleau D, Thomas-Slayter B, Wangari E. Eds. Feminist Political Ecology. Global Issues and Local Experiences. London and New York: Routledge 1996; pp. 27-62.

[19] Hecht J. Extractive Communities, biodiversity and gender issues in Amazonia. Proceeding of the International Conference on Women and Biodiversity. Washington D.C: World Resources Institute 1995.

[20] Espinosa MC. Género, Participación Comunal y Manejo de Recursos en la Comunidad San Martín, Reserva Nacional PacayaSamiria (Gender, Community Participation and Resource Management in San Martin del Tipishca, Pacaya-Samiria National Reserve). Iquitos, Peru: WWF/AIF-DK1997.

[21] Espinosa MC. Análisis Socio-Demográfico de los Ribereños del río Napo y Mazan, Loreto. Socio Demographic Analysis of the Riparian People in Napo and Mazan, Loreto. Diagnóstico del distrito de Mazan Lima: CE\&DAP/CARE. J Dev Soc 1991; 24(4): 489-521.

[22] Espinosa MC. Análisis Demográfico de Lambayeque, Loreto y San Martín. Analysis of factors affecting the sustainability of farming systems in peru. Final report for the ford foundation. Lima CE\&DAP 1991b.

[23] Espinosa MC. Análisis Social de los Sistemas de Producción en Costa y Selva: Género, Autopercepciones y Actitudes relacionadas con el Medio Ambiente (Social Analysis of Coastal and Amazon Farming Systems in Peru: Gender, Self-perception and Attitudes related with the Environment). Final report ford the project analysis of factors affecting sustainability in farming systems of peru. Lima: CE\&DAP 1991.

[24] Espinosa MC. Markets, Livelihood and Gender: The Ribereños of the Napo and Mazan Rivers in Loreto. Cancun: Annual Meeting of the Society for Applied Anthropology 1994.

[25] Agreda V, Espinosa MC. Desarrollo Sostenible: El Nuevo Dorado para la Amazonía? (Sustainable Development: A New Utopia for the Amazon?) Debate Agrario No. 12 Lima: Ediciones CEPES 1991.

[26] Espinosa MC. Gender, ethnicity and health in the amazon. Health Ethn 2009b; 14(5): 423-437.

[27] Espinosa MC. What has Globalization to do with Wildlife Use in the Remote Amazon? Exploring the links between macro-economic changes, markets and community entitlements. J Dev Soc 2008; 24(4): 489-521.

[28] Altarama A. De Nativos a Ribereños. Un Recorrido a lo Largo de su Historia Comunal. Lima, 1992.

[29] Moran E. Through Amazon Eyes: The Human Ecology of Amazon Populations. Iowa: Iowa University Press 1993.
[30] Bergman R. Economía Amazónica. Estrategias de Subsistencia en las riberas del Ucayali, Perú. Lima: CAAP 1990.

[31] Hiraoka M. Mestizo subsistence in riparian amazonía. Natl Geograph Res 1985 (1): 236-46.

[32] Barham BL, Coomes OT, Craig B, Tarassoff P. Wealth and the Forest Peasant Household: Evidence from the Tahuayo and the Pacaya-Samiria, Loreto. Manuscript 1995.

[33] Escobar A. Encountering Development: The Making and Unmaking of the Third World. Princeton, USA: Princeton University Press 1995.

[34] San Roman J. Perfiles Históricos de la Amazonía Peruana. Lima: Ediciones Paulinas-CETA 1975.

[35] Valcarcel. Evolución del rol productivo de la Amazonía. In: Barclay F. Ed. Amazonia 1940-1990 El extravío de una ilusión Lima: Terra Nuova/CISEPA 1991.

[36] Villarejo A. Así es la Selva. Iquitos: CETA 1979.

[37] Stocks A. Los nativos invisibles. Lima: CAAP 1981.

[38] Coomes OT. Making a Living in the Amazon Rain Forest: Peasants, Land and Economy in the Tahuayo, Peru. Ph.D. [Dissertation) Madison: University of Wisconsin 1992.

[39] Minzenberg E. Hunting and Households in PDS Sâo Salvador. Acre, Brazil. PhD. [Dissertation] Gainesville (FL): University of Florida 2005.

[40] Aramburu CE. Proceso rural y estrategias de sobrevivencia familiar: Notas teóricas y metodológicas. In: La Cuestión Rural en el Perú. Lima: PUCP 1983; pp. 71-98.

[41] Agreda V. El impacto del ajuste estructural en la economía y los recursos naturales de los productores ribereňos. Arequipa: SEPIA V 1993.

[42] Escobal J. Impacto de las políticas de ajuste estructural sobre la pequeña agricultura. Proceedings of the Seminario de Ajuste Estructural, Políticas Agrarias y Sector Agropecuario en Bolivia, Chile, Ecuador y Perú. Lima, Perú: CEPES/FAO 1996.

[43] González de Olarte E. La dimensión ambiental de las políticas económicas (The environmental dimension of macroeconomic policies). SEPIA 1993

[44] Espinosa MC. What has Globalization to do with Wildlife Use in the Remote Amazon? Exploring the links between macro-economic changes, markets and community entitlements. J Dev Soc 2009; 24(2): 489-521.

[45] Poats S, Schmink M, Spring A, Eds. Gender issues in farming systems research and extension. Boulder: Press Westview 1998.

[46] Feldstein H.S. and S. Poats. Eds. Working together: gender analysis in agriculture. Connecticut: Kumarian Press 1990.

[47] Kabeer N. Reversed Realities. Gender Hierarchies in Development Thought. London: Verso 1994.

[48] Thomas-Slayter B, Esser LA, Shields MD. Tools of Gender Analysis. A Guide to Field Methods for Bringing Genderinto Sustainable Resource Management. Worcester, Massachussets: Clark University 1993.

[49] Jackson C. Men's work, masculinities and gender divisions of labour. J Dev Stud 1999; 36(1): 89-108

[50] Murphee R. Social structure and sex antagonism. In: Gross D, Ed. Peoples and cultures of native south america. New York: The Natural History Press 1973.

[51] Barclay F. Para Civilizarlas Mejor. Reflexiones acerca de programas de desarrollo para mujeres en sociedades amazónicas. Shupihui 1994; No.33-6.

[52] Çagatay N. Engendering Macro-economics. In: Gutierrez M., Ed. Macro-Economics: Making Gender Matter Concepts, Policies and Institutional Change in Developing Countries. London: Zed Books 2003.

[53] Campillo F. Unpaid Household Labor: A conceptual approach. In: Gutierrez M. Ed. Macro-Economics: Making gender matter concepts, policies and institutional change in developing Countries London: Zed Books 2003.

[54] Wagley C. Amazon Town: A study of man in the tropics. London: Oxford University Press; 1964.

[55] Caritinari J. Cocama Leader. Personal Interview. Iquitos 1997.

[56] Mayoux L. Beyond naivety: women, gender inequality and participatory development. Dev Change 1995; 26: 235-58. 